\title{
Halal Tourism Development Strategy Program in Indonesia
}

\author{
Suesilowati \\ Diploma III Hospitality \\ Akademi Pariwisata Pertiwi \\ Jakarta, Indonesia \\ susibaik2010@gmail.com
}

\author{
Rina Ekawati \\ Pertiwi Research Institutions and Community Service \\ Jakarta, Indonesia \\ rina.ekawati@pertiwi.ac.id
}

\begin{abstract}
This study aims to identify opportunities and challenges of halal tourism as well as internal and external environment conditions accordingly strategies for halal tourism development program in Indonesia can be formulated. Data is collected through observation, interview and questionnaire. Researcher used qualitative method such as SWOT analysis based on IFAS matrix (Internal Factor Analysis Summary) and EFAS (External Factor Analysis Summary) and matrix analysis SWOT (Strengths, Weaknesses, Opportunities, Threats). Specific strategies from the SWOT analysis (Strengths, Weaknesses, Opportunities, Threats), namely: strategy SO (Strength Opportunity), strategy ST (Strength Threat), strategy WO (Weakness Opportunity) and strategy WT (Weakness Threat). Results analysis of Halal Tourism Implementation in Indonesia showed in quadrant II, which is Diversification Strategy, the consequently strategy which will be developed, includes develop a good public education program on religion, culture, tourism management for human resources in Indonesia, as well as individual education programs on Halal Tourism development strategy in accordance with the government policy.
\end{abstract}

Keywords-halal tourism, opportunity, challenges, strategy, development

\section{INTRODUCTION}

Sharia-based tourism (halal tourism) has become a new trend in the development of tourism in many parts of the world.

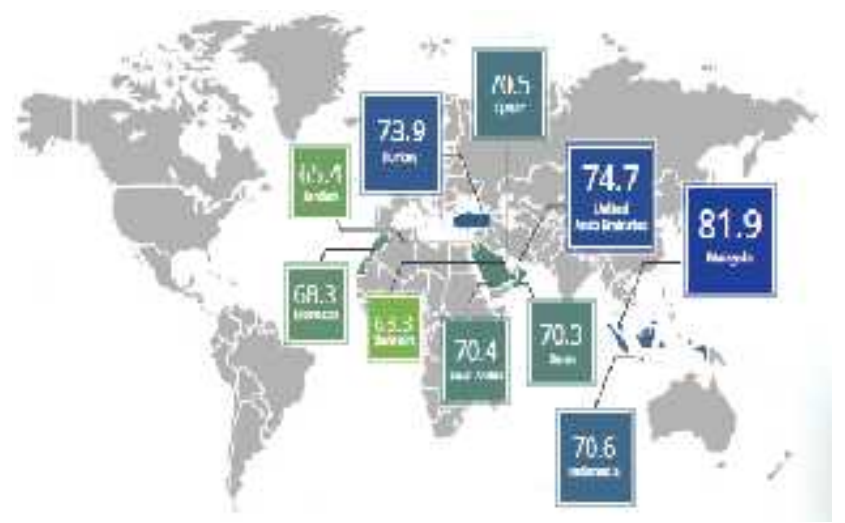

Fig. 1. The spread of halal tourism in the world
The Figure 1 shows that there are scores of each country whereas the top 10 can be seen from the Tabel 1 . In the end of 2015, it is estimated that 1.4 billion Muslims is scattered around the world. Pew Research Center's Forum on Religion and Public Life estimates the world's Muslim population will grow from 1.4 billion to about 2.2 of the total world population in 2030. It means targeting Muslim travelers is an important decision because Muslim globally spends approximately 137 billion dollars in 2012 for tourism (excluding Hajj and Umrah), while global total expenditure during the same period is estimated at 1.095 trillion dollars. We can say that the global Muslim tourism market is equivalent to $12.5 \%$ of the global total expenditure. In the future, Muslim tourist expenditures is expected to grow to \$ 181 billion in 2018 (State of the Global Islamic Economy 2013 Report) while report of Global Muslim Travel Index 2015 mentions Muslim travel segment has a value of 145 billion US dollars from 108 million Muslim travelers. The figure is predicted to rise to 150 million by 2020 with a market value of 200 billion US dollars.

In the end of 2015, the recognition of potential country for halal travel was presented in the World Halal Travel Summit 2015 in Abu Dhabi, United Arab Emirates. The event was followed by 200 countries with 14 categories of contest. Indonesia successfully brought home three categories; (1) the World's Best Halal Tourism Destination, (2) the World's Best Halal Honeymoon Destination and (3) the World's Best Friendly Family Hotel. This condition is a favorable opportunity for the tourism industry. Therefore, many countries responded by targeting Muslims as potential travelers candidate. 
TABLE I. TOP 10 HALAL TOURISM DESTINATIONS

\begin{tabular}{|c|c|c|c|}
\hline Bank & cramaibtain & Bescririon & Saite \\
\hline 1 & 1 & Malzyia & 81.2 \\
\hline 2 & 2 & Listed Arab Emirase: & $7 \pi$ \\
\hline 3 & 3 & Turkey & 730 \\
\hline 4 & 4 & induissis & 706 \\
\hline 5 & ; & Qutar & 70.5 \\
\hline 6 & 6 & JasdiAnabia & 704 \\
\hline 7 & 7 & Omas & $\pi$ \\
\hline 8 & 9 & Horceco & 583 \\
\hline y & iv & broder & bist \\
\hline 10 & 11 & 3ethria & 633 \\
\hline
\end{tabular}

Some developed countries such as Queensland, Hong Kong and Japan have seriously developed halal tourism focusing service in businesses, hotels, and restaurants. Halal tourism growth as seen in New Zealand and Australia shows that Muslims prefer to visit non-Muslim. In the State of The Global Islamic Economy 2013 Report, non-Muslim countries are able to manage potential Muslim tourist with more maximal. For example, Japan has a prayer hall at the airport and most hotels there provide kosher food, as well as Korea which provides food labeled halal.

In 2010, from 237.641.326 Indonesian, 206 million (around $87 \%$ ) are Muslims, means it could support the development of Halal Tourism. Essentially, Indonesian Muslims are in the top 10 population who mostly travel, but unfortunately Indonesia is not yet in the list of top 10 Muslim tourist destinations (Utomo, 2014, the Global Muslim Traveler). In table 1 Halal Tourism Destinations in the World, Indonesia was ranked fourth meaning the great potential of Halal Tourism has not been managed optimally.

In order to improve competitiveness on tourism, Indonesia should target the market of Muslim travelers around the world. As the consequences, various stakeholders should focus on how to meet the needs of Muslim travelers who come to Indonesia. Therefore, further study to determine the development strategies of Halal Tourism is urgently required and needs to be done soon in Indonesia together with analyzing the opportunities and strengths that will encourage tourists to visit Indonesia, and the challenges and weaknesses that constrains the of growth halal tourism in Indonesia. It is very important to identify all of those opportunities and strengths as well as challenges and weaknesses, so we could understand well what are wishes and needs of Muslim travelers. This identification can also help the Government of Indonesia in setting various strategies of sharia tourism (halal tourism) development.

How was halal tourism development strategy conducted in Indonesia?

The purpose of this research, are:

a. To see what are the opportunities, strengths, challenges and weaknesses Indonesia in developing the halal tourism.

b. To formulate halal tourism development strategy in order to improve tourism targets Indonesia
Halal Tourism means tourist destinations or attractions which employ Islamic Values, sell kosher food, provide halal hotel, and also provide many places of worshipping. Travel Sharia Concept is defined as a process of integrating Islamic values into travel activities (Tourism Review in Kurniawan 2015); Islamic values as fundamentals of Muslims is the baseline of tourism activities, starting from accommodation, restaurants, until other activities which always refer to Islamic norms (Tourism Review in Kurniawan, 2015).

Sharia or Halal tourism is activities supported by a wide range of facilities and services provided by communities, businesses, central governments, and local governments that comply with sharia rules (Kemenpar, 2012).

Shakiry in Suherlan (2015) defines the concept of sharia travel as a form of tourism activities, not only limited to religious tour, but includes all forms of tourist activities, which are promoting the principles of Islamic Sharia in the management.
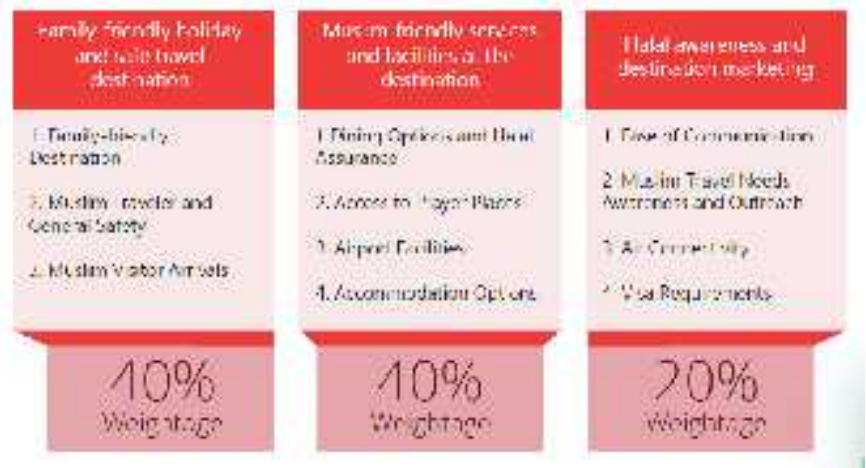

Fig. 2. The 11 Criteria That Make Up The Global Muslim Travel Index 2016

The concept of Sharia is the actualization of the Islamic concept where the value of clean and unclean become the benchmark, meaning all aspects of tourism activities could not be separated from the halal certification as the requirements for tourism business in conducting halal tourism (Chookaew in Suherlan, 2015).

The Master Card-Crescent Rating Global Muslim Travel Index (GMTI) gives benchmark of important criteria to track the health and growth of each segment to every stakeholder in the travel and hospitality sectors, including tourists, tourism boards, economists, travel service providers, investors and industry specialists, as shown in the Figure 2.

In addition to the 11 criteria GMTI, Halal Tourism development also needs to be strengthened by the presence of well managed human resources as well as government policies. 
TABLE II. SWOT ANALYSIS, WEIGHT, SCALE AND VALUE

\begin{tabular}{|c|c|c|c|c|}
\hline No & Dimension & $\begin{array}{l}\text { Weig } \\
\text { ht }\end{array}$ & Scale & $\mathrm{e}^{\text {Valu }}$ \\
\hline \multirow[t]{15}{*}{1} & Strength & & & \\
\hline & $\begin{array}{l}\text { Availability of activities such as } \\
\text { shopping, travel, architecture, art and } \\
\text { culture, nature and wildlife, beaches, } \\
\text { etc. }\end{array}$ & 0.1 & 4 & 0.4 \\
\hline & Number of visitors & 0.05 & 2 & 0.1 \\
\hline & $\begin{array}{l}\text { Percentage of Muslim visitors as } \\
\text { compared to percentage of total } \\
\text { visitors }\end{array}$ & 0.05 & 2 & 0.1 \\
\hline & $\begin{array}{l}\text { The availability of halal food in the } \\
\text { main cities of destinations }\end{array}$ & 0.05 & 2 & 0.1 \\
\hline & Access to worshipping vicinity & 0.05 & 4 & 0.2 \\
\hline & $\begin{array}{l}\text { Availability of proper ablution } \\
\text { facilities in public places and transit }\end{array}$ & $\begin{array}{l}0.02 \\
5\end{array}$ & 2 & 0.05 \\
\hline & The availability of worshipping & 0.02 & 4 & 0.1 \\
\hline & $\begin{array}{l}\text { vicinity in public places and transit } \\
\text { Availability of Halal food / restaurants } \\
\text { in public and transit areas }\end{array}$ & $\begin{array}{l}5 \\
0.05\end{array}$ & 3 & 0.15 \\
\hline & Type of accommodation: apartment or & 0.02 & 1 & 0.02 \\
\hline & motel available for families travelers & 5 & & 5 \\
\hline & $\begin{array}{l}\text { Percentage of Muslim population in } \\
\text { the city of destinations }\end{array}$ & 0.05 & 3 & 0.15 \\
\hline & Speaking manner & 0.05 & 2 & 0.1 \\
\hline & Informative behaviour & $\begin{array}{l}0.02 \\
5\end{array}$ & 2 & 0.05 \\
\hline & Value of Strength & 0.55 & & $\begin{array}{l}1.52 \\
5\end{array}$ \\
\hline \multirow[t]{11}{*}{2} & Weaknesses & & & \\
\hline & travelled safe environment & 0.1 & 3 & 0.3 \\
\hline & $\begin{array}{l}\text { Halal certification ecosystems in place } \\
\text { of destinations }\end{array}$ & 0.05 & 1 & 0.05 \\
\hline & Safe \& clean toilets at the airport / & 0.02 & 1 & 0.02 \\
\hline & transit / tourist destination & 5 & & 5 \\
\hline & Flight connectivity & 0.05 & 3 & 0.15 \\
\hline & Visa Requirements & 0.02 & 1 & 0.02 \\
\hline & & 5 & & 5 \\
\hline & Professionalism & 0.1 & 3 & 0.3 \\
\hline & $\begin{array}{l}\text { Indonesian government policy on } \\
\text { Indonesia culture grand design }\end{array}$ & 0.05 & 3 & 0.15 \\
\hline & Value of Weakness & 0.45 & & 1 \\
\hline \multirow[t]{5}{*}{3} & Opportunity & & & \\
\hline & Family holiday destinations & 0.1 & 3 & 0.3 \\
\hline & $\begin{array}{l}\text { Conferences, workshops, seminars } \\
\text { and other educational activities related } \\
\text { to halal food, Halal travel, Muslim } \\
\text { consumers etc. }\end{array}$ & 0.2 & 2 & 0.4 \\
\hline & $\begin{array}{l}\text { Holiday destination marketing } \\
\text { targeted at Muslim travelers }\end{array}$ & 0.2 & 4 & 0.8 \\
\hline & Value of Opportunity & 0.5 & & 1.5 \\
\hline \multirow[t]{11}{*}{4} & Threats & & & \\
\hline & $\begin{array}{l}\text { Number of hotels promoted as } \\
\text { Muslim-friendly }\end{array}$ & 0.1 & 1 & 0.1 \\
\hline & Muslim visitor guide and information & 0.02 & 1 & 0.02 \\
\hline & issued by holiday destinations & 5 & & 5 \\
\hline & Ease of communication & 0.1 & 2 & 0.2 \\
\hline & Islamically knowledgeable $\mathrm{t}$ & 0.1 & 4 & 0.4 \\
\hline & $\begin{array}{l}\text { Keep abreast on the development of } \\
\text { Halal Tourism in Indonesia }\end{array}$ & 0.05 & 2 & 0.1 \\
\hline & Having knowledge on potential & 0.02 & 2 & 0.5 \\
\hline & destinations of Halal Tourism & 5 & & \\
\hline & $\begin{array}{l}\text { Indonesia government policies on } \\
\text { halal tourism }\end{array}$ & 0.1 & 3 & 0.3 \\
\hline & Value of Threats & 0.5 & & $\begin{array}{l}1.62 \\
5\end{array}$ \\
\hline
\end{tabular}

Development of Halal Tourism is not exclusive tour for Muslim only as non-Muslims can also enjoy the services of ethical sharia, not only pilgrimage and religious site, but also the availability of supporting facilities, such as restaurants and hotels which provide halal food and places of worshipping. Halal tourism also includes products and travel services, as well as tourist destination which not conflict with sharia values and ethics. Halal tourism could be an alternative for travelers who want to try new travel concept, not only conventional travel. But all parties must put into consideration branding and packaging complies with the right concept of sharia.

\section{Methodology}

This study used a qualitative descriptive approach, careful measurement of certain social phenomena.

Descriptive qualitative analysis, IFAS (Internal Factors Analysis Summary), EFAS (External Factors Analysis Summary) and SWOT (Strengths Weaknesses Opportunities Threats) will be used to systematically identify the various factors and formulate strategies, so in the end, development program can be made for recommendation to competent parties.

The SWOT analysis is conducted after interviewing and distributing questionnaires to 11 speakers in the development of Halal Tourism research indicator instrument.

\section{RESULT AND ANALYSIS}

Results of SWOT analysis using IFAS and EFAS is presented in the Tabel 2.

\section{A. Data interpretation}

Magnitude range selection score will determine the accuracy of ratings. commonly used is from 1 to 10 , assuming a value of 1 means the lowest score and 10 the highest mean score.

The weight is an assessment of the factors point to comparing the level of importance to other factors point values that have been obtained (the same value range with the number of factors point) divided by the large number of factors point), and based on table 2. SWOT Analysis, Weight, Scale and Value, showed the score calculation (a) and weight (b) point a factor as well as the number of total multiplication scores and weights $(\mathrm{c}=\mathrm{a} \mathrm{x}$ b) on any factor S-W-O-T are Internal factors is an internal environment that consists of strength and weaknesses. Strength factors obtained a total value of 1,525, whereas the weaknesses only 1 , thus the strength value exceeds the value of weaknesses, which is a positive 0,525 as values or points on the $\mathrm{X}$ axis.

External Factors, opportunity factor obtained a total value of 1.5 , while the challenge (Threat) only 1,625 , thus the opportunity is smaller than the value of the threat, which is negative $\mathbf{- 0 1 2 5}$ as values or points on the $\mathrm{Y}$ axis.

SWOT quadrant with coordinate point $(0525 ;-0125)$ 


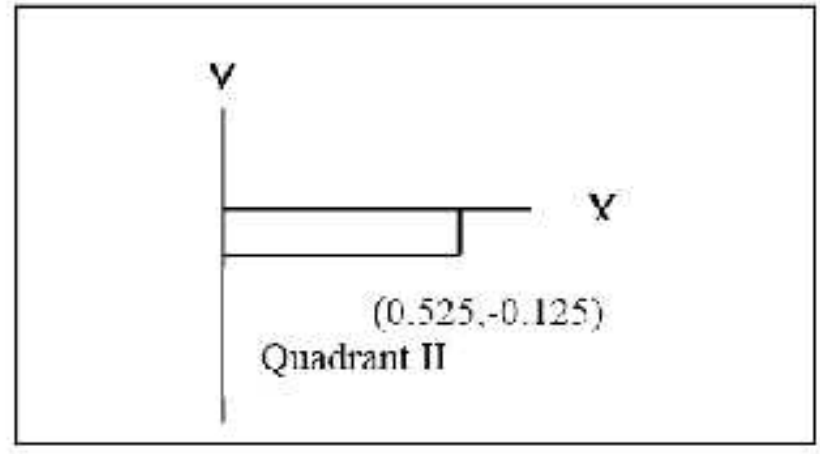

Fig. 3. SWOT Quadrant

Based on figure 3, showed implementation of halal tourism in Indonesia is in quadrant II (positive, negative). This position indicates that Halal Tourism is strong in the implementation but also have several major challenges. Recommended strategy to address this situation is diversification strategy whichmean in the development of Halal Tourism a number of major challenges need to be dealth with all difficulties it may entails. Consequently, it calls for an alternative tactical strategy. The Strategys are:

\section{1) Strength and opportunity}

Setting up a tourism destination, worshipping facilities, halal food restaurants, family travelers hotel / motel.Conduct conferences, workshops, seminars and other educational activities related to halal food, Halal travel, Muslim consumers, etc. Serve the customers excellently and enhance it with good marketing strategy.

\section{2) Weaknesses and Opportunity Strategy:}

Establish a safe travelled environment, ensure flight connectivity and visas to halal tourism destinations, reduce human error with professional human resources, and implement government policy onculture grand design to fully optimatize texisting potentials

\section{3) Strength and threats Strategy:}

Prepare and promote tourism destination, means of communication, worshiping facilities, halal food restaurants, family travelers hotel / motel. Conduct conferences, workshops, seminars and other educational activities related to religion, Halal food, Halal travel, Muslim consumers in order to improve the human resources knowledge for a complete understanding of religion, recognize Halal Tourism destination potential and its development and able to produce a guidebook for tourists visiting Halal Tourism destinations, as well as develope tourism destinations in accordance with government policy on Halal Tourism

\section{4) Weaknesses and threats Strategy:}

Common understanding on Halal Tourism, government policy implementation, preparing tourism destination, sustaining infrastructure, and professional human resources.

\section{CONCLUSION}

Halal Tourism strategies development conducted in Indonesia, are as follows: Halal Tourism implementation in Indonesia falls in quadrant II, which is Diversification Strategy, such as develop a good public education program on religion, culture, tourism management for human resources in Indonesia, as well as individual education programs on Halal Tourism development strategy in accordance with the government policy. This way, human resources in Indonesia will have an integral understanding, as well as professionally coached to obtain a certificate of competence in this field, try to establish a safe and complete Halal Tourism destinations which include attractions, arts and culture, hotel, restaurant, flight connectivity, improved communication channels, and worshipping facilities, in accordance with government policy. Also provide excellent services with Islamic values bearing in mind Indonesia as a pluralistic country and doing promotion of Halal Tourism destinations in various ways possible to add value.

\section{REFERENCES}

Ade Suherlan. ( 2015).”Jakarta Public Perception of Islamic Tourism." The Journal of Tauhidinomics

Haidar Tsany Alim,etc. (2014). Journals" Analysis Of Islamic Tourism Potential To Optimize The Creative Industries In Central Java And Yogyakarta"

http://www.republika.co.id/berita/koran/syariahkoran/14/06/12/n71rm615-Alamsyah, I. E. (2014, June 12). Islamic Tourism Need Support Local Government: Mahaka Group. (I. Curley, Editor) Picked August 26, 2014.

http://indonesia.travel/id/news/detail/1666/banda-aceh-as world-islamic-tourism ; Wonderful Indonesia. (2015, April 01). Retrieved April 30, 2015.

https://www.crescentrating.com/travel-index-ranking.html, download October $25^{\text {th }} 2016$

Kurniawan Gilang Widagdyo.( 2015)."Market Analysis Halal Tourism Indonesia" The Journal of Tauhidinomics, Jakarta.

Minister of Tourism (2015); Attraction assessment report development of sharia in

Minister of Tourism and Creative Economy of the Republic of Indonesia; A copy of the Regulation Number 2, 2014 on Guidelines for the Implementation of Sharia Business Hotel

Prasetyo Adi Sulistyono. (2016). Scientific Journals "Attribution analysis of islam, and drivers factor of motivation muslim tourist visit aceh province".

P2PAR ITB and Halal Centre of Salman. (2016) International Tourism confrence.paper presentation member" Bandung. 